\title{
Pulmonary endocrine cells in anthracosilicotic lungs
}

\author{
J.R. Gosney*, J. Peers*, C. Beesley*, E. Gradwell**
}

Pulmonary endocrine cells in anthracosilicotic lungs. J.R. Gosney, J. Peers, C. Beesley, E. Gradwell. CERS Journals Ltd 1997.

ABSTRACT: It has been suggested by some studies of human and animal lungs that the products of pulmonary endocrine cells, particularly gastrin-releasing peptide, might play a role in fibrogenesis, but more recent detailed studies of fibrotic human lungs have failed to confirm this. We have made a detailed quantitative examination of a series of fibrotic human lungs to see if we could determine whether there was any relationship between endocrine cells and fibrosis.

Using immunocytochemistry, we investigated the morphology, content, distribution and number of pulmonary endocrine cells in 15 pairs of fibrotic lungs from coal miners, and compared their features with those of equivalent cells in agematched controls.

Proliferation of endocrine cells was seen in the lungs of just two miners, in which it was focal and associated with acute bronchitis and bronchopneumonia. There was no difference between the miners and controls in the appearance (mostly solitary cells), content (predominantly gastrin-releasing peptide and calcitonin), distribution (mainly in small bronchi and bronchioles), or number (4.5 vs 4.1 cells per 10,000 epithelial cells, respectively) of endocrine cells.

It seems unlikely that the substances secreted by these cells play any role in stimulating fibrosis in human lungs, but rather that they have a function in the inflammatory response to pulmonary injury.

Eur Respir J 1997; 10: 388-391.
*Dept of Pathology, University of Liverpool, Liverpool, UK. **Whiston Hospital, Prescot, Merseyside, UK.

Correspondence: J.R. Gosney

Dept of Pathology

University of Liverpool

P.O. Box 147

Liverpool L69 3BX

UK

Keywords: Anthracosilicosis coal miners

pulmonary endocrine cells pulmonary fibrosis

Received: March 121996

Accepted after revision November 21996
Several pulmonary diseases provoke proliferation of pulmonary endocrine cells (PECs), often with an accompanying relative or absolute alteration in their secretory products [1], which normally include gastrin-releasing peptide (GRP), calcitonin (CT), calcitonin gene-related peptide (CGRP), and serotonin (5-hydroxytryptamine (5HT)).

The stimulus for these changes and their consequences are a matter of debate, but they are probably a response to pulmonary injury, the products secreted by the endocrine cells acting to control repair and regeneration of damaged pulmonary tissues [2].

One result of pulmonary injury is fibrosis, and there is evidence that PECs might be involved in its pathogenesis [3-8]. In a previous study of 49 pairs of lungs affected by diffuse fibrosis at various stages of development, we could find no differences in the pulmonary endocrine system in comparison with control lungs, apart from a single focus of proliferation in an area affected by pneumonia [9]. In 1991, GubBelmans et al. [10] compared numbers of PECs in 12 pairs of anthracosilicotic lungs from coal miners with numbers in 14 controls. There was no overall difference between the two groups, although PECs were more numerous in the lungs of five coal miners with a history of respiratory insufficiency. This suggested that hypoxia might be related to their number but, as with our study [9], that fibrosis was probably not.
Because of these uncertainties, we thought it would be of value to examine PECs in a further series of anthracosilicotic lungs from coal miners, to investigate not only their overall number and distribution, but also their content, and also to determine any topographical relationship between changes in these cells and the pathological changes present in the lungs.

\section{Patients and material}

Lungs from 15 coal miners coming for necropsy to Whiston District General Hospital, Prescot, Merseyside, UK, in which there had been a history of anthracosilicosis (table 1), were compared with those from 10 age- and sex-matched controls, without clinical or pathological evidence of pulmonary disease. The mean age of both groups, all male, was 75 yrs. All necropsies were performed within $24 \mathrm{~h}$ of death.

\section{Methods}

Twenty tissue blocks were taken from each pair of lungs, in order to provide an even distribution of pulmonary tissue. Sampling was identical for all lungs. Blocks were fixed for $24 \mathrm{~h}$ in Zamboni's solution, embedded in paraffin wax, and sections were cut at $4 \mu \mathrm{m}$. The 
Table 1. - Clinical and pathological details of the 15 pairs of coal miners lungs studied

\begin{tabular}{|c|c|c|}
\hline $\begin{array}{l}\text { Study } \\
\text { No. }\end{array}$ & $\begin{array}{l}\text { Age } \\
\text { yrs }\end{array}$ & Pulmonary pathology \\
\hline 1 & 78 & Simple coal workers' pneumoconiosis \\
\hline 2 & 76 & $\begin{array}{l}\text { Simple coal workers' pneumoconiosis, active } \\
\text { fibrosis, pulmonary thromboembolism }\end{array}$ \\
\hline 3 & 86 & $\begin{array}{l}\text { Simple coal workers' pneumoconiosis, sil- } \\
\text { icotic nodules up to } 1.0 \mathrm{~cm} \text {, pulmonary } \\
\text { thromboembolism }\end{array}$ \\
\hline 4 & 92 & Massive fibrosis \\
\hline $5 *$ & 66 & $\begin{array}{l}\text { Simple coal workers' pneumoconiosis, chron- } \\
\text { ic bronchitis and emphysema, focal bron- } \\
\text { chopneumonia }\end{array}$ \\
\hline 6 & 78 & $\begin{array}{l}\text { Simple coal workers' pneumoconiosis, lym- } \\
\text { phangitis carcinomatosa }\end{array}$ \\
\hline 7 & 67 & Massive fibrosis \\
\hline 8 & 82 & $\begin{array}{l}\text { Simple coal workers' pneumoconiosis, active } \\
\text { fibrosis }\end{array}$ \\
\hline 9 & 68 & $\begin{array}{l}\text { Simple coal workers' pneumoconiosis, sil- } \\
\text { icotic nodules up to } 0.5 \mathrm{~cm} \text {, lymphangitis } \\
\text { carcinomatosa }\end{array}$ \\
\hline 10 & 64 & $\begin{array}{l}\text { Simple coal workers' pneumoconiosis, severe } \\
\text { focal bronchitis and bronchopneumonia }\end{array}$ \\
\hline 11 & 82 & Massive fibrosis, bronchopneumonia \\
\hline 12 & 63 & Simple coal workers' pneumoconiosis \\
\hline 13 & 75 & Simple coal workers' pneumoconiosis \\
\hline 14 & 73 & $\begin{array}{l}\text { Simple coal workers' pneumoconiosis, pul- } \\
\text { monary thromboembolism }\end{array}$ \\
\hline $15^{*}$ & 79 & $\begin{array}{l}\text { Simple coal workers' pneumoconiosis, sil- } \\
\text { icotic nodules up to } 0.4 \mathrm{~cm} \text {, active fibrosis }\end{array}$ \\
\hline
\end{tabular}

*: only these two subjects had respiratory insufficiency.

sections were stained with haematoxylin and eosin and by an elastic and van Gieson method for histopathological examination. Closely adjacent sections were immunolabelled using the avidin-biotin complex (ABC) technique [11], and at the dilutions shown for protein gene product (PGP) 9.5 [12] (Biogenesis, Bournemouth, UK; 1: 400) and chromogranin A [13] (Dako, High Wycombe, UK; $1: 150$ ), general markers of cells of the diffuse endocrine system [1], and for a series of secretory products, both normal (GRP (Dako; 1:400), CT (Dako; 1:2000) and CGRP (Milab, Malmo, Sweden; 1:3000), and aberrant (leucine (leu-) enkephalin (CRB, Northwich, UK; 1:2000), human growth hormone (HGH; Dako; 1:200), adrenocorticotrophin (ACTH; Dako; 1:1000) and cholecystokinin (CCK; CRB; 1:2000) [1].

Following treatment with $3 \%$ hydrogen peroxide in distilled water for $30 \mathrm{~min}$ to inactivate endogenous peroxidase, and with $5 \%$ normal swine serum for $1 \mathrm{~h}$ to prevent nonspecific protein binding, sections were incubated with primary antiserum for $30 \mathrm{~min}$ at room temperature. They were then incubated for $30 \mathrm{~min}$ with biotin-conjugated swine anti-rabbit immunoglobulin (Dako) diluted 1:200 in normal swine serum, and with ABC (Dako), also for $30 \mathrm{~min}$. Following addition of hydrogen peroxide, the reaction product was finally visualized by treatment with diaminobenzidine. Appropriate positive and negative tissue controls were employed throughout.

Pulmonary endocrine cells were quantitated, as in previous studies from this laboratory $[14,15]$, by a method similar to that employed by GuBBELMANS et al. [10], in which they are expressed in terms of the total epithelial population as "endocrine cells per 10,000 epithelial cells". Providing that endocrine cells are confined to airways, as is usually the case in human lungs, this is an extremely accurate method of quantitating them, since it is unaffected by the state of distention of the lungs and also takes account of any generalized alteration in the size of the epithelial population [15].

\section{Results}

Numbers of endocrine cells in the 10 pairs of control lungs, as identified by immunoreactivity for PGP 9.5, ranged 3.4-6.2, with a mean of 4.5 per 10,000 epithelial cells. As identified by their content of chromogranin A, there were about $10 \%$ less than this (mean 4.1 per 10,000 epithelial cells). Only five clusters of PECs were seen in the control lungs, two in each of two cases and one in a third, so that the vast majority of cells were solitary (fig. 1). Most were located in small intrapulmonary airways and terminal bronchioles; none were seen in alveolar ducts or alveoli. Sixty five percent contained GRP, $30 \%$ CT, and the majority of the rest CGRP. No "ectopic" substances were identified.

The pathological changes in the fibrotic lungs of the coal miners are summarized in table 1 . Two patients had respiratory insufficiency during life; in one it was attributable to chronic bronchitis and emphysema, and in the other to advanced silicosis.

In all but two of these 15 subjects, PECs were entirely normal in morphology, number, distribution and content. They ranged in frequency $2.8-6.0$ per 10,000 epithelial cells, with a mean of 4.1 , and contained predominantly GRP. As with the control lungs, the vast majority were solitary (fig. 2); only eight clusters were found, two in each of four pairs of lungs. No ectopic secretory products could be identified.

In two pairs of lungs (case Nos. 5 and 10), PECs showed a localized increase in their number (figs. 3 and 4 ), but the normal predominance of GRP was unaltered and no aberrant products were detected within them. In both cases, the increase was confined to areas of lung affected by acute bronchitis and bronchopneumonia. Although case No. 5 had a history of respiratory insufficiency ante mortem, there was nothing to suggest this was related to the focal change in PECs described. The pulmonary endocrine system in case No. 15 , the second

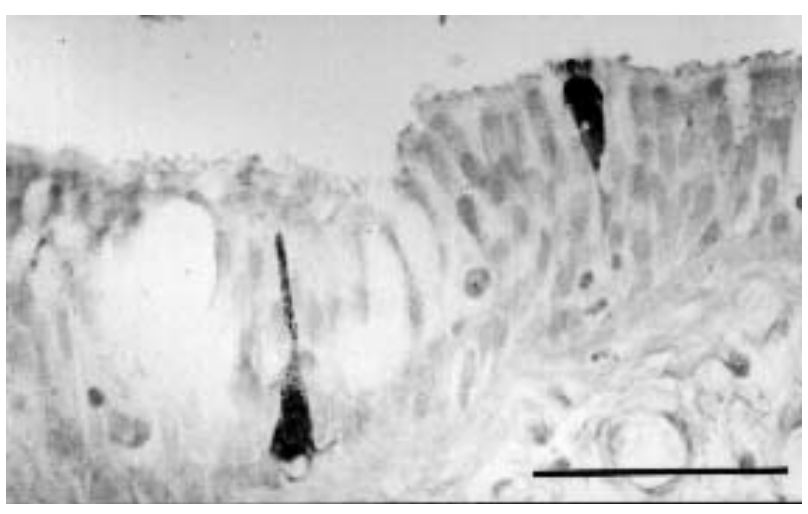

Fig. 1. - Two solitary bronchial endocrine cells from one of the controls. The one on the left has a conspicuous cytoplasmic process extending towards the lumen. (Avidin-biotin complex (ABC) technique for chromogranin $\mathrm{A}$; internal scale bar $=50 \mu \mathrm{m})$. 


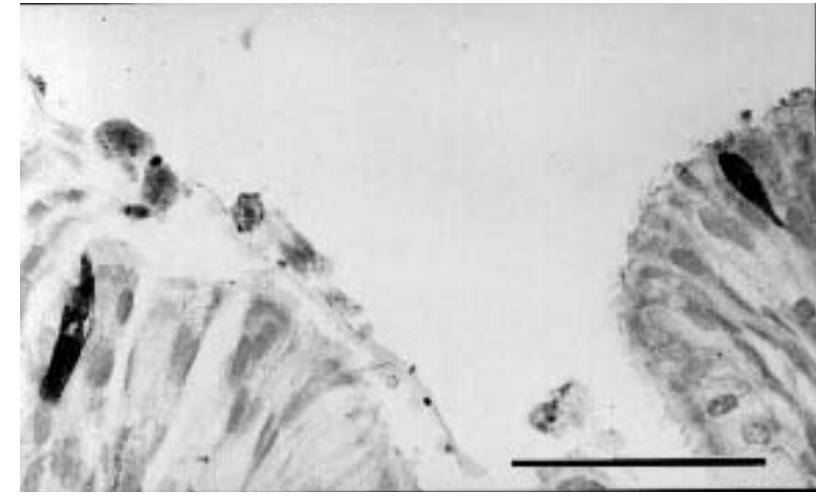

Fig. 2. - Two normal solitary bronchial endocrine cells from one of the coal miners (case No. 8). (Avidin-biotin complex (ABC) technique for chromogranin A; internal scale bar $=50 \mu \mathrm{m})$.

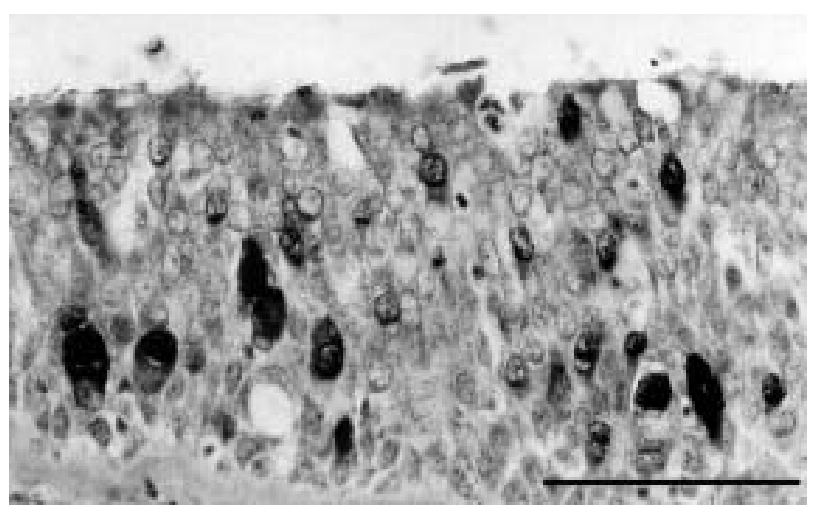

Fig. 3. - Increased numbers of endocrine cells in an inflamed bronchus in a coal miner's lung affected by bronchitis and bronchopneumonia (case No. 5). The oblique nature of the section reveals the extent of the proliferation. (Avidin-biotin complex (ABC) technique for chromogranin $\mathrm{A}$; internal scale bar $=50 \mu \mathrm{m})$.

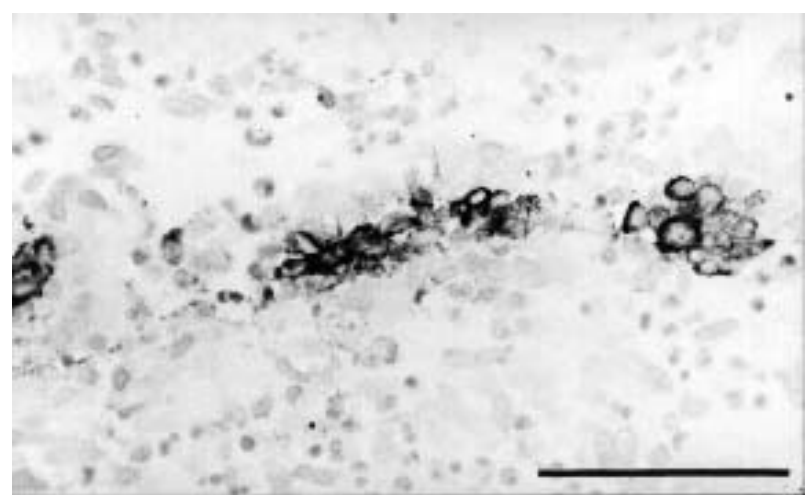

Fig. 4. - Increased numbers of endocrine cells in a heavily inflamed terminal bronchiole in a coal miner's lung affected by bronchitis and bronchopneumonia (case No. 10). The epithelium is degenerating and the proliferating cells have formed small groups. (Avidin-biotin complex $(\mathrm{ABC})$ technique for chromogranin $\mathrm{A}$; internal scale bar $=50$ $\mu \mathrm{m})$.

of the two with a history of respiratory insufficiency, was entirely normal. There was no relationship between PEC number, distribution and content, and any other pathology.

\section{Discussion}

The contention that the products of PECs might play a role in pulmonary fibrogenesis arose as a result of observations from studies both of human [7, 8, 16, 17] and animal $[3,4]$ lungs, which described an association between endocrine cell proliferation and fibrosis, whether focal or diffuse. This idea was supported by studies of the function of the predominant secretory product of PECs, GRP, which showed it to be trophic not only to bronchial epithelium [18], but also pulmonary fibroblasts [19]. Furthermore, studies of lungs of rats developing pulmonary fibrosis due to asbestos revealed a significant increase in the concentration of GRP within them of the order of 2-2.5 times [5, 6].

Despite this evidence, however, two recent detailed pathological studies of human lungs affected by naturally-occurring fibrosis of variable aetiology $[9,10]$ have failed to reveal any association between proliferation of PECs and fibrosis, suggesting, instead, respiratory insufficiency or inflammation as causative factors. The results of the present study again fail to show any association between changes in the pulmonary endocrine system and fibrosis, but suggest, yet again, that inflammation, in this case due to acute bronchitis and bronchopneumonia, might be a factor. All of the PECs in the lungs included in the present study were in airways so we cannot exclude the possibility that the development of parenchymal endocrine cells might play a role in the development of some cases of interstitial pulmonary fibrosis. Endocrine cells are sometimes found in alveolar ducts and alveoli of diseased lungs, but are uncommon [1].

Whatever the precise functions of the pulmonary endocrine system in fully-developed human lungs, a role in the response to injury, especially when inflammation is provoked and probably involving the regulation of regeneration of damaged tissues, seems most likely. Further physiological as well as pathological studies will be required to confirm this hypothesis and to clarify the processes involved.

Acknowledgements: The authors thank S. Kelly and A.V. Spedding, who were invaluable in collecting the cases studied.

\section{References}

1. Gosney JR. Endocrine pathology of the lung. Chapter 7. In: Recent Advances in Histopathology. Anthony PP, MacSween RNM, eds. New York, Churchill Livingstone, 1994; pp. 147-165.

2. Miller YE. Pulmonary neuroendocrine cells and lung development: dim outlines emerge. J Clin Invest 1994; 91: 1861 .

3. Johnson NF, Wagner JC, Wills HA. Endocrine cell proliferation in the rat lung following asbestos inhalation. Lung 1980; 158: 221-228.

4. Sheppard MN, Johnson NF, Cole GA, Bloom SR, Marangos PJ, Polak JM. Neuron specific enolase immunostaining: a useful tool for the microscopical detection of endocrine cell hyperplasia in adult rats exposed to asbestos. Histochemistry 1982; 74: 505-513.

5. Day R, Lemaire I, Masse S, Lemaire S. Pulmonary bombesin in experimentally induced asbestosis in rats. Exp Lung Res 1985; 8: 1-13. 
6. Day R, Lemaire S, Nadeau D, Keith I, Lemaire I. Changes in autacoid and neuropeptide contents of lung cells in asbestos-induced pulmonary fibrosis. Am Rev Respir Dis 1987; 136: 906-915.

7. Johnson DE, Georgieff MK. Pulmonary neuroendocrine cells: their secretory products and their potential roles in health and chronic lung disease in infancy. Am Rev Respir Dis 1989; 140: 1807-1813.

8. Aguayo SM, King TE, Waldron JE, Sherritt KM, Kane MA, Miller YE. Increased pulmonary neuroendocrine cells with bombesin-like immunoreactivity in adult patients with eosinophilic granuloma. J Clin Invest 1990; 86: 838-844.

9. Wilson NJE, Gosney JR, Mayall F. Endocrine cells in diffuse pulmonary fibrosis. Thorax 1993; 48: 1252-1256.

10. Gubbelmans HLL, Maesen BLP, Kouldstaal J, Thunnissen FBJM. Neuroendocrine cells in anthracosilicotic lungs. Eur Respir J 1991; 4: 824-828.

11. Hsu SM, Raine L, Fanger H. Use of avidin-biotin peroxidase complex $(\mathrm{ABC})$ in immunoperoxidase techniques: a comparison between $\mathrm{ABC}$ and unlabelled antibody (PAP) procedures. J Histochem Cytochem 1981; 29: 577-580.

12. Thompson RJ, Doran JF, Jackson P, Dhillon AP, Rode J. PGP 9.5, a new marker for vertebrate neurones and neuroendocrine cells. Brain Res 1983; 278: 224-228.
13. Lauweryns JM, Van Ranst L, Lloyd RV, O'Connor DT. Chromogranin in bronchopulmonary neuroendocrine cells: immunocytochemical detection in human, monkey and pig respiratory mucosa. J Histochem Cytochem 1987; 35: 113-118.

14. Gosney JR, Sissons MCJ, Allibone RO. Neuroendocrine cell populations in normal human lungs: a quantitative study. Thorax 1988; 43: 878-882.

15. Gosney JR. Neuroendocrine cell populations in postnatal human lungs: minimal variation from childhood to old age. Anat Rec 1993; 236: 177-180.

16. Gould VE, Linnoila RI, Memoli VA, Warren WH. Neuroendocrine components of the bronchopulmonary tract: hyperplasias, dysplasias and neoplasms. Lab Invest 1983; 49: 519-537.

17. Tsutsumi Y, Osamura RY, Watanabe K, Yanaihara N. Immunohistochemical studies on gastrin-releasing peptide and adrenocorticotrophic hormone-containing cells in the human lung. Lab Invest 1983; 43: 623-632.

18. Siegfried JM, Guentert PJ, Gaither AL. Effects of bombesin and gastrin-releasing peptide on human bronchial epithelial cells from a series of donors: individual variation and modulation by bombesin analogs. Anat Rec 1993; 236: 241-247.

19. Rozengurt E. Bombesin-induction of cell proliferation in 3 T3 cells. Ann NY Acad Sci 1988; 547: 277-292. 